\title{
高职工程管理类专业实践教学改革研究
}

\author{
石硕 \\ 湖北水利水电职业技术学院 \\ DOI:10.32629/er.v2i3.1707
}

[摘 要] 本文结合高职工程管理类专业特点, 从实践教学现状进行分析,探索高职工程管理类专业实践教学改革原则和改革 途径,提出实践教学体系的构建框架和思路,更好地促进学生专业技能的掌握,推动专业建设与发展。

[关键词] 工程管理; 实践教学; 改革

实践教学是整个高职教学体系中重要的组成部分, 是高 职教育人才培养过程中不可缺少的重要环节。面对社会发展 对工程管理类技术技能人才需求量不断增长的新时期, 如何 加强工程管理类专业内涵建设, 开展实践教学改革研究, 完 善实践教学体系, 提升工程管理类毕业生专业技术技能, 提 高工程管理类专业适应社会需求能力, 是我们当前面临的重 要课题。

\section{1 高职工程管理类专业实践教学现状分析}

\section{1 存在重理论轻实践思想}

工程管理类专业具有工程专业和管理专业双重属性, 属 于交叉型学科, 专业课程横跨工程技术和经济管理领域, 其 对学生的专业实践技能要求较高。但由于受传统教育思想的 影响, 仍然存在以理论课程为主, 实践课程迁就理论课程的 现实情况, 没有将实践教学作为专业教学的重要核心环节, 专业实践课占比较小。

\section{2 实践教学安排存在随意性}

由于工程管理类专业实践教学专业性较强, 又因专业教 师因承担较大理论课的工作量, 导致在实践教学上随意安排 时有发生。一是随意安排指导教师, 专业能力强的老师基本 以上专业理论课为主, 实践指导老师往往由实验员或其他非 骨干教师担任; 二是实践教学内容安排随意, 往往为了便于 学生完成任务而降低学习要求; 三是时间安排上随意, 专业 实践教学周不能很好地与专业理论课相呼应, 过于迎合教师 时间; 四是组织管理较随意, 未能很好地执行上课时间要求。

\section{3 实践教学内容存在滞后性}

随着社会的不断发展, 工程领域的相关知识和技术更新 较快, 未将国家新规范、新规定等纳入教学, 存在实践教学内 容与行业技术要求脱节的问题, 导致学生职业能力不能完全 满足实际工作需求。

\section{4 实践教学缺乏系统设计}

在制定专业人才培养方案时, 未能科学规划、系统设计, 导致各实践课程之间相互独立, 缺乏逻辑性。

\section{5 实践教学评价缺乏过程考核}

工程管理类专业实践教学具有十分重要的实践操作特 性, 既讲究过程又注重结果, 但现实实践教学过程中往往只 依据实践报告作为评判成绩的唯一标准, 而忽视了过程评价,
不能全面反映学生学习情况。

\section{2 高职工程管理类专业实践教学改革原则}

2.1 科学性与特色性相结合原则

工程管理类专业在进行实践教学设计时要遵循专业技 术和技能知识特点, 以培养学生技术应用能力为主线, 结合 各高职院校实践教学实际和特色, 科学安排实践教学内容。

2.2 实用性与时代性相结合原则

社会进步与技术发展是紧密相连的, 工程管理类实践教 学要考虑时代发展特点, 以职业岗位需求为导向, 充分体现 实践教学的时代性和实用性。

\section{3 理论与实践相结合原则}

工程管理实践教学要建立在掌握理论知识的前提下进 行, 打破纯理论教学和纯实践教学的界限, 做好理论教学和 实践教学的一体化设计, 使理论与实践有机结合, 提高学生 的技能学习效率。

\section{3 高职工程管理类专业实践教学改革途径}

3.1 科学制定实践教学实施方案

实践教学实施方案是有关专业实践教学的标准化指南, 包括实践教学大纲、教学方法、教学内容、教学目标、教学 模式、教学标准、考核方式及标准等内容, 以标准来衡量实 践教学效果, 充分发挥实践教学的最大效用。实践教学实施 方案重点在于突出实际操作特性, 着重提高学生的专业技能, 培养学生的职业岗位能力、职业素质及人际关系能力, 让学 生在实践教学过程中体验工作流程, 感受企业文化、提高适 岗能力, 解决理论教学脱离工作实际的现实问题。

\section{2 完善校内外实践条件}

完备的实训条件是实践教学的顺利进行的可靠保障。无 论校内还是校外实训基地, 要满足实践教学设施设备齐全, 工艺、技术和管理等符合社会、企业需求, 体现时代特征等 基本条件, 在此基础上体现产学研一体化的功能, 以保证实 训基地可持续发展, 不被社会进步和发展所淘汰。

\section{3 构建多层次实践教学环节}

工程管理类专业实践教学要严格按照工程或工作流程 来进行教学设计, 需要结合工作实际和专业特点, 根据循序 渐进的原则, 以培养学生职业能力为本位, 按照认知一单项 技能一综合模拟一顶岗实习等顺序设计实践教学关节。同时 
在内容的组织上, 一方面要反映现代企业的高新技术、管理 等实际, 另一方面也体现企业对员工素质的要求, 使学生既 得到专业技能的训练, 又能感受现代企业文化。

\section{4 建设 “教练型” 教师队伍}

实践教师本领过硬, 是学生完成实训项目锻炼实践技能 的根本保障。因此, 建立一支理论知识扎实、素质过硬、实 践教学设计开发和指导能力强的教练型教师队伍就变得十 分重要。工程管理类专业实践教学指导教师要自身具备实际 操作能力, 掌握技术发展、社会发展需求以及学生学习实际 情况, 有针对性地开发和设计实训教学, 演绎 “教练” 角色, 才能更好地帮助和指导掌握专业知识和技能。

\section{5 建立实践教学质量保障机制}

结合专业诊断与改进工作要求, 做好实践教学质量保障 机制的建立。一是科学制定工程管理类专业实践教学发展规 划 (或计划), 明确发展目标, 指明实践教学发展方向; 二是根 据不同专业制定各专业实践教学标准和实践教学考核标准, 对实践教学进行考核, 规范实践教学过程; 三是建立健全实 践教学相关管理制度, 严格教学过程管理。同时建立实践教 学质量保障机制, 切实提高学生实践技能的掌握。

\section{4 高职工程管理类专业实践教学体系构建}

工程管理类专业实践教学体系框架示意图如下:

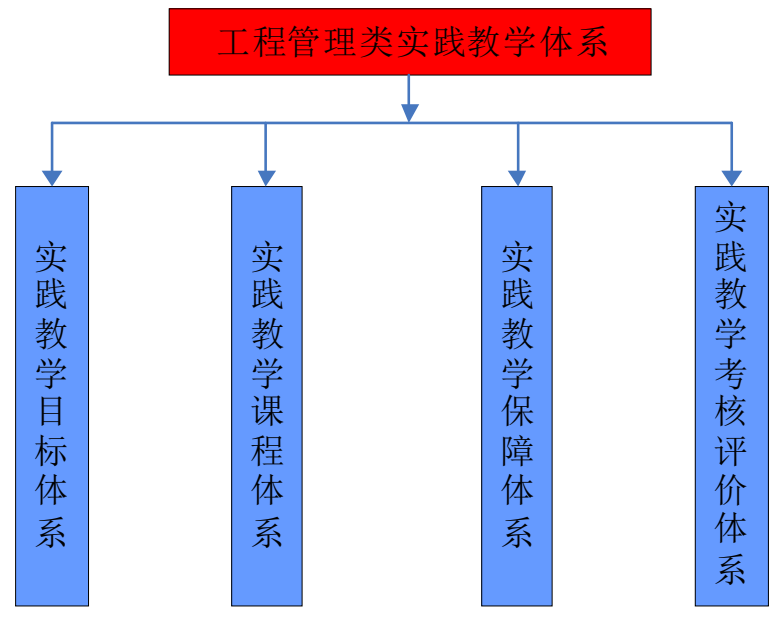

4. 1 基于职业岗位需求的实践教学目标体系

工程管理类专业人才培养目标共同点就在于培养能够从 事工程项目招投标、施工全过程管理的高素质劳动者和技术 技能人才。工程项目要求管理人员具备 “技能型” 和 “复合 型” 的人才特质, 需要具备工程管理相关的技术、管理、法律 方面的知识和技能, 这种素质和技能必须通过系统的实践教 学培养才能获得。通过对工程管理相关职能岗位的分析, 按照 基础能力一单项技能一综合能力一岗位能力的逻辑顺序, 明 确各项目管理员、生产经理、经营经理、总工程师、项目经 理、质量主管、安全主管等岗位的教学目标, 构建工程管理类 专业的实践教学目标体系, 使实践教学更有针对性。
4.2 基于教学目标的实践教学课程体系

按照工程项目各管理岗位的职业标准, 以各岗位的实践 教学目标为指引, 科学设置各实践教学课程, 使每一个职业 岗位技能都能落实到相应的实践课程中去。构建以岗位能力 为核心的工程管理类专业实践教学课程体系, 制定课程标准, 全面培养学生的岗位综合能力和提升综合素质, 使学生获得 更好的适岗能力, 能够较快较好地履行岗位职责。

4.3 构建全面的实践教学保障体系

全面的实践教学保障体系包括教师队伍、实践教学基 地、实践教学相关制度文件和教学模式。一是结合工程管理 类相关专业技术、技能要求, 有针对性地培养 “教练型” 教 师队伍, 努力提高教师的实际操作能力, 同时聘请企业一线 专家、技术能手担任兼职指导教师。二是创新校企合作模式， 依托企业建设和完善校内外实习实训基地, 形成实践教学基 地群, 为实践教学提供完备的条件。三是制定和完善相关制 定、教学文件, 规范实践教学过程。四是创新实践教学模式, 可以企业岗位和生产需求, 采用多学期制进行实践教学, 最 大限度地发挥实践教学效用。

4.4 建立实践教学考核评价体系

结合各实践课程标准, 建立实践教学考核评价体系, 对 实践教学进行考核评价, 一是对学生的实践技能掌握情况实 行量化考核, 将实践学习过程纳入考核因素之一。二是对照 考核课程标准, 对指导教师教学效果进行考核评价, 将评价 结果纳入教师学期业务能力考核范围。三是适时引进第三方 评价, 利用第三方评价机构对实践课程教学评价, 促进实践 教学水平不断提高。

总之, 对工程管理类专业实践教学进行改革探索, 构建 符合人才培养目标的实践教学体系, 是职业教育人才培养的 实际需求, 能够有效地促进工程管理类专业建设与发展。

\section{[参考文献]}

[1]陈建国,许凤.工程管理专业实践教学体系构建研究 [J].高等建筑教育,2010,(01):89-94.

[2]孙虹,刘红,程炳.工程管理专业实践教学改革探讨 [J]. 高等建筑教育,2009,(02):127-130.

[3]余璠璟,张敏莉.工程管理实践教学体系建设研究 [J]. 高等建筑教育,2013,(01):109-112.

[4]张颖,胡晓娜, 付立涁.工程管理专业实践教学体系优 化研究 [J].高等建筑教育,2013,(03):115-118.

[5]汤金华.高职院校工科专业实践教学体系的构建 [J]. 河南职业技术师范学院学报(职业教育版),2006,(01):1 15-117.

[6]吴敏,赵荣辉.高职院校工科类专业实践教学体系重 新构建研究——岳阳职业技术学院为例 [J]. 黄冈职业技术 学院学报,2008,(02):21-24. 